\title{
Pengaruh Ukuran Perusahaan, Likuiditas, Profitabilitas, dan Solvabilitas Terhadap Opini Audit Going Concern pada Perusahaan Manufaktur yang Terdaftar di Bursa Efek Indonesia Tahun 2018-2020
}

\author{
Maria Cristanti Nababan ${ }^{1}$, Otto Ruth Sonya Damanik ${ }^{2}$, Maghfirah ${ }^{3,}$ Keumala Hayati $^{4}$ \\ Universitas Prima Indonesia, Medan 1,2,3,4 \\ mariachristantinababan@gmail.com, sonyagunawan90@gmail.com, \\ new.maghfirah99@gmail.com, keumalahayatihakim@ gmail.com
}

*Penulis Korespondensi

Diajukan : 6 Desember 2021

Disetujui : 1 Januari 2022

Dipublikasi : 4 Januari 2022

\begin{abstract}
The continuity of the compant's business among the various risk that arise as a result of internal or external factors are the expectations of all entities in effort to achieve the company' goals. The purpose of this study is to find out what the effect of company size, liquidity, solvency and profitability on Going Concern audit opinion of manufacturing companies listed on the Indonesia Stock Exchange for the 2018-2020 period. Secondary data is used from the Indonesia Stock Exchange, the source of data is from www.idx.co.id. In this study, the sampling method selected according to the purposive sampling method was used and 44 companies were selected as samples. Data analysis using Logistic Regression test. The results showed that the size, liquidity, profitability and solvency of the company affected the Going Concern audit opinion.
\end{abstract}

Keywords: Company Size; Going concern audit opinions; Liquidity; Profitability, Solvency

\section{PENDAHULUAN}

Auditor bertanggung jawab mengevaluasi apakah terdapat kesangsian besar terhadap kemampuan entitas dalam mempertahankan kelangsungan hidupnya dalam periode waktu tertentu. Dalam SPAP SA 341, tanggung jawab auditor adalah untuk memperoleh bukti audit yang cukup dan tepat tentang ketepatan penggunaan asumsi kelangsungan usaha dalam penyusunan dan penyajian laporan keuangan dan untuk menyimpulkan apakah terdapat suatu ketidakpastian material tentang kemampuan entitas untuk mempertahankan kelangsungan usahanya. Pendapat atas kemampuan perusahaan mempertahankan keberlanjutan usahanya menjadi sangat penting untuk diungkapkan, karena laporan keuangan sebuah perusahaan disusun menggunakan asumsi bahwa perusahaan akan tetap beroperasi untuk jangka waktu yang lama, sehingga apabila muncul keraguan dari auditor terhadap kemampuan perusahaan dalam mempertahankan kelangsungan hidupnya, maka hal tersebut harus segera diungkapkan. Dalam penelitian Tarihoran (2019), salah satu factor yang mempengaruhi opini audit going concern yaitu kondisi keuangan dari perusahaan tersebut.

Kondisi keuangan perusahaan merupakan kunci utama dalam melihat apakah perusahaan akan mampu mempertahankan kelangsungan usahanya atau tidak pada masa yang akan datang. Kondisi keuangan perusahaan juga dapat terlihat dari laporan keuangan yang telah disajikan oleh 
manajemen. Untuk mengukur kinerja keuangan maka digunakan rasio keuangan. Rasio keuangan tersebut meliputi profitabilitas, likuiditas, ukuran perusahaan, dan solvabilitas terhadap opini audit going concern.

Ukuran perusahaan bisa diproduksikan berbentuk total kekayaan, jumlah pendapatan, serta kapitalisasi pasar. Bertambah besarnya aset, kapitalisasi pasar dan total pendapatan, maka ukuran perusahaan bertambah besar juga. Hartono (2020: 460) menjelaskan, ukuran perusahaan mendeskripsikan ukuran dari perusahaan melalui total aset, logaritma natural digunakan sebagai pengukurnya. Menurut penelitian Gama (2020), ukuran perusahaan mempengaruhi opini audit going concern.

Likuiditas ialah perusahaan berkemampuan mendapatkan uang kas dalam jangka pendek guna terpenuhinya kewajiban dan tergantung pada aset lancar, arus kas dan kewajiban perusahaan (Subramanyam (2017:10)). Jika kewajiban jangka pendek tidak mampu terpenuhi oleh perusahaan, kegiatannya akan terganggu dan bisa menyebabkan pertanyaan tentang kemampuan auditor untuk melanjutkan kelangsungan perusahaan. Hasil penelitian Nazir (2019) membuktikan bahwa likuidtas berpengaruh opini audit going concern. Namun, hasil penelitian dari sudarno (2010) memperoleh hasil bahwa likuiditas tidak berpengaruh signifikan terhadap opini audit going concern.

Solvabilitas ialah rasio yang dipergunakan dalam menilai kemampuan perusahaan agar kewajiban jangka panjang terpenuhi. Likuiditas jangka panjang perusahaan diukur oleh rasio ini, terkonsentrasi di sisi kanan neraca atau pos jangka panjang (Mamduh M. Hanafi (2018: 81)). Peneliti mengambil penelitiandilaksanakan sebelumnya Sutedja (2017) dan Aquariza (2018) memaparkan bahwa solvabilitas yang dinyatakan dengan debt to assets ratio mempengaruhi opini audit going concern dari auditor. Namun penelitian dari Jahli (2019) justru menunjukkan bahwa solvabilitas tidak berpengaruh signifikan terhadap opini audit going concern.

Hanafi (2019:81) menjelaskan bahwa penggunaan rasio profitabilitas guna mengukur kemampuan perusahaan untuk mendapatkan laba atas aset, modal tertentu, dan tingkat pendapatan. Umumnya, laba digunakan untuk mengukur kinerja suatu perusahaan. Keputusan bisnis para kreditor/investor dipengaruhi juga oleh profitabilitas perusahaan. Dari penelitian sebelumnya, menyimpulkan bahwa profitabilitas berpengaruh signifikan terhadap opini audit going concern yaitu penelitian yang dilakukan Sutedja (2018) dan Kristiana (2019). Namun, penelitian yang dilakukan Nazir (2019) menunjukkan hasil yang bertolak belakang bahwa profitabilitas tidak berpengaruh terhadap opini audit going concern.

Melalui penelitian ini, dapat ditemukan bukti empiris mengenai faktor-faktor keuangan yang mempengaruhi opini audit going concern, sehingga dapat menambah wawasan dan ilmu pengetahuan tentang opini audit going concern, serta menjadi tambahan literatur referensi untuk penelitian-penelitian selanjutnya. Secara praktis,hasil penelitian dapat dimanfaatkan oleh para auditor sebagai bahan pertimbangan untuk meninjau secara lebih teliti terkait dengan factor-faktor yang mempengaruhi opini audit going concern, sehingga dengan pertimbangan analisis yang matang dan hati-hati dapat menberikan opini audit going concern yang tepat pada perusahaan, yang segi dari keuangan memiliki indikasi keberlangsungan usaha diragukan. Selain itu, hasil penelitian dapat juga dijadikan acuan oleh manajer dalam mengelola perusahaan dengan baik, sehingga dapat mencegah perusahaan mendapatkan opini audit going concern dari auditor. Penelitian ini juga dapat bermanfaat sebagai acuan bagi investor dan kreditur dalam menilai keberlangsungan usaha dari suatu perusahaan, sehingga dapat menganalisis lebih mendalam terkait dengan pengambilan keputusan untuk penanaman investasi dan pemberian kredit kepada perusahaan.

\section{STUDI LITERATUR}


Owner: Riset \& Jurnal Akuntansi

e-ISSN : 2548-9224 | p-ISSN : 2548-7507

Volume 5 Nomor 2, Agustus 2021

DOI : https://doi.org/10.33395/owner.v5i2.573

\section{Pengaruh ukuran perusahaan terhadap opini audit going concern}

Ukuran perusahaan yaitu nilai yang bisa mengkategorikan sebuah perusahaan ke dalam kategori kecil atau besar, yang bisa dilihat pada penjualan bersih dan total aset, Hartono (2018). Dengan demikian, kian besar perusahaan, peluang memperoleh opini audit going concern kian kecil. (Pradika dan suryono 2017) membuktikan bahwa ukuran perusahaan memberi pengaruh bermakna pada opini audit going concern.

\section{Pengaruh likuiditas pada opini audit going concern}

Likuiditas merupakan perusahaan yang berkemampuan guna pemenuhan kewajiban jangka pendek secara tepat waktu. Faktanya, perusahaan yang tidak likuid membuat kesulitan perusahaan untuk membayarkan kewajiban jangka pendeknya. Jika ini terus berlanjut, besar kemungkinan perusahaan tidak akan dapat bertahan dan melanjutkan kegiatannya.

Current Ratio (CR) merupakan rasio pengukuran likuiditas. Semakin rendah likuiditas perusahaan, berarti perusahaan tidak akan bisa membayar lunas kewajiban jangka pendeknya yang jatuh tempo. Dari sudut pandang opini audit going concern, bertambah kecilnya likuiditas perusahaan, maka bertambah rendah likuiditas perusahaan, dan kemampuannya untuk membayarkan kewajiban jangka pendek dengan aset lancar kian rendah juga. Hal ini cenderung menimbulkan banyaknya piutang tak tertagih, yang mengakibatkan pertanyaan dari auditor tentang kelangsungan hidup perusahaan. Di sisi lain, jika likuiditas perusahaan meningkat, perusahaan harus mampu melunaskan kewajiban jangka pendek tepat waktu. Penelitian Ira Christiana (2017) menghasilkan bahwa likuiditas memberi pengaruh negatif bermakna pada opini audit going concern.

\section{Pengaruh profitabilitas pada opini audit going concern}

Analisis profitabilitas bertujuan mengukur profitabilitas suatu perusahaan. ROA ialah rasio laba/rugi bersih pada jumlah aset. Rasio tersebut sebagai gambaran kemampuan perusahaan ketika mengelola keuntungan serta kinerja tata kelola perusahaan secara menyeluruh.

Bertambah tinggi ROA, maka pengelolaan aset perusahaan akan semakin efisien. Sehingga, rasio profitabilitas yang lebih tinggi memperlihatkan peningkatan kinerja operasi perusahaan, maka auditortidak menyatakan opini audit going concern perusahaan dengan rasio profitabilitas tinggi. Arma (2017), Noverio (2018) dan Pradica (2017) menunjukkan bahwa profitabilitas berpengaruh yang signifikan pada opini audit going concern.

\section{Pengaruh solvabilitas pada opini audit going concern}

Ukuran perusahaan yang berkemampuan menutup kewajiban keuangan disebut rasio solvabilitas. Solvabilitas didasarkan pada total pembiayaan yang asalnya dari pinjaman perusahaan kepada kreditur. Debt to Assets Ratio digunakan untuk mengukur rasio solvabilitas. Tingginya rasio solvabilitas dapat berpengaruh negatif terhadap posisi keuangan perusahaan.

Rasio solvabilitas yang semakin tinggi, menjadikan kinerja keuangan perusahaan dan ketidakpastian keberlangsungan hidupnya semakin buruk. Hal ini meningkatkan kemungkinan bahwaperusahaan akan mengeluarkan opini audit going concern. Penelitian sebelumnya dari Noverio (2019), Lie dkk (2017) dan Ajikusuma (2017), menunjukkan bahwa opini audit going concernmendapat pengaruh secara bermakna dari solvabilitas. 
Owner: Riset \& Jurnal Akuntansi

e-ISSN : 2548-9224 | p-ISSN : 2548-7507

Volume 5 Nomor 2, Agustus 2021

DOI : https://doi.org/10.33395/owner.v5i2.573

\section{Kerangka Konseptual}

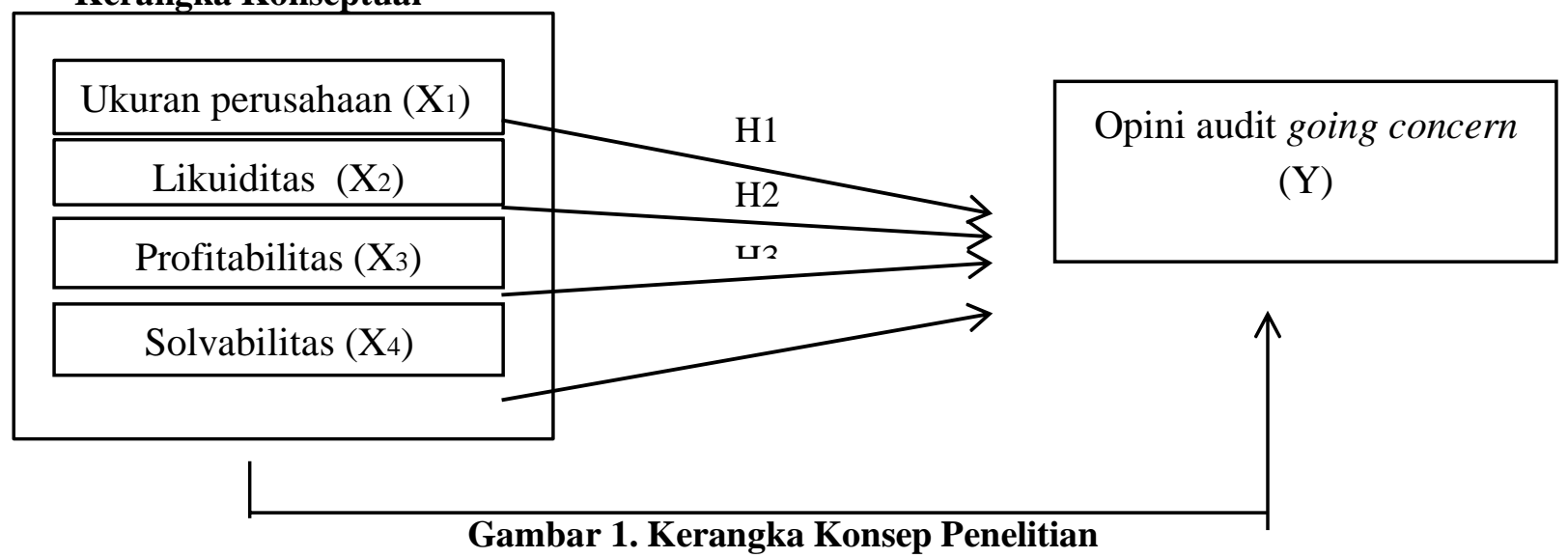

\section{Hipotesis Penelitian}

Adapun hipotesis pada penelitian yaitu:

H1 : Ukuran perusahaan memberi pengaruh terhadap opini audit going concern di perusahaan manufaktur yang tercatat di BEI tahun 2018-2020.

$\mathrm{H} 2$ : Likuiditas memberi pengaruh pada opini audit going concern di perusahaan manufaktur yang tercatat di BEI tahun 2018-2020.

H3 : Profitabilitas memberi pengaruh terhadap opini audit going concern di perusahaan manufaktur yang tercatat di BEI tahun 2018-2020.

H5 : Solvabilitas, Ukuran perusahaan, Solvabilitas, dan Profitabilitas secara bersamaan memberi pengaruh terhadap opini audit going concern terhadap perusahaan manufaktur yang tercatat di BEI periode 2018-2020.

H4 : Profitabilitas memberi pengaruh terhadap opini audit going concern pada perusahaanmanufaktur yang tercatat di BEI tahun 2018-2020.

\section{METODE}

Statistik deskriptif menjadi pendekatan yang dipakai pada penelitian ini, dengan tipe penelitiangabungan guna mengukur pengaruh dari variabel bebas pada variabel terikat.

\section{Populasi dan sampel}

Penelitian ini mencakup perusahaan manufaktur yang tercatat di BEI sepanjang penelitian 2018- 2020. Purposive sampling menjadi metode dalam mengambil sampel. Beberapa kriteria yang menjadi dasar dalam proses pengambilan sampel di penelitian ini, yaitu:

Tabel 1. Kriteria pengambilan sampel

\begin{tabular}{|c|l|c|}
\hline No & \multicolumn{1}{|c|}{ Kriteia } & Jumlah \\
\hline 1 & Perusahaan manufaktur yang terdaftar di BEI tahun 2018-2020 & 168 \\
\hline 2 & $\begin{array}{l}\text { Perusahaan yang tidak mempublikasikan laporan keuangan di } \\
\text { BEI tahun 2018-2020 }\end{array}$ & $(40)$ \\
\hline 3 & $\begin{array}{l}\text { Tidak mengalami laba bersih periode laporankeuangan selama } \\
\text { tahun 2018-2020 }\end{array}$ & $(49)$ \\
\hline 4 & Perusahaan yang menggunakan mata uang asing & Jumlah pengamatan yang diteliti \\
\hline \multicolumn{2}{|r|}{} \\
\hline
\end{tabular}


Owner: Riset \& Jurnal Akuntansi

e-ISSN : 2548-9224 | p-ISSN : 2548-7507

Volume 5 Nomor 2, Agustus 2021

DOI : https://doi.org/10.33395/owner.v5i2.573

\section{Variabel dan Defenisi Operasional}

Terdapat 2 jenis variabel, ialah variabel terikat dan bebas.

a. Variabel Dependen

Variabel terikat dengan lambang huruf $(\mathrm{Y})$, yaitu jenis variabel yang bergantung atau dijelaskan pada variabel bebas. Pada penelitian, variabel terikatnya yaitu:

$\mathrm{Y}=$ opini audit going concern

Opini audit going concern ialah opini audit yang diubah yang auditor ungkapkan ketika terdapat ketidakjelasan mengenai kemampuan going concern perusahaan guna melanjutkan keberlangsungan usahanya, atau ketika ada ketidakpastian, jaminan signifikan tentang kelangsungan hidup entitas untuk menjalankan bisnisnya.

b. Variabel Independen

Variabel independen dengan lambang huruf (X), yaitu variabel yang berpengaruh akan variabel terikat. Berikut variabel bebas pada penelitian yakni ukuran perusahaan, profitabilitas, likuiditas, serta solvabilitas.

Tabel 2. Defenisi Operasional

\begin{tabular}{|c|c|c|c|}
\hline $\begin{array}{c}\text { Jenis } \\
\text { Variabel }\end{array}$ & Defenisi & Indikator & $\begin{array}{l}\text { Skala } \\
\text { Ukur }\end{array}$ \\
\hline $\begin{array}{r}\text { Ukuran } \\
\text { perusahaan }\end{array}$ & $\begin{array}{l}\text { Ukuran perusahaan bisa dipahami sebagai } \\
\text { ukuran perusahaan berdasarkan } \\
\text { kemampuan keuangan perusahaan dan } \\
\text { bidang kegiatan di } \\
\text { mana perusahaan berkembang. } \\
\text { (Nawang dan widi 2016). }\end{array}$ & $\begin{array}{l}\text { Size }=\log (\text { Total } \\
\text { Aktiva }) \\
\text { (Nawang dan widi } \\
\text { 2016) }\end{array}$ & Nominal \\
\hline Likuiditas & $\begin{array}{l}\text { Indikator yang mengukur } \\
\text { kemampuan perusahaan untuk melunasi } \\
\text { seluruh kewajiban } \\
\text { keuangan jangka pendeknya denganjatuh } \\
\text { tempo asset lancarnya } \\
\text { (Kristina 2012). }\end{array}$ & $\begin{array}{c}\mathrm{CR}=\text { Total } \\
\text { aktiva lancarTotal } \\
\text { hutang lancar } \\
\text { (Kristina } \\
\text { 2012) }\end{array}$ & Skala \\
\hline Profitabilitas & $\begin{array}{l}\text { Rasio mengukur kemampuan } \\
\text { perusahaan untuk menghasilkan } \\
\text { keuntungan di semua asset yangtersedia ( } \\
\text { Kasmir 2016). }\end{array}$ & $\begin{array}{c}\text { ROA } \\
\text { Laba bersih } \\
\text { setelah pajak= } \\
\text { Total asset } \\
\text { (Kasmir } \\
\text { 2016) }\end{array}$ & Skala \\
\hline Solvabilitas & $\begin{array}{l}\text { Rasio yang mengukur sejauh manaasset } \\
\text { perusahaan didanai oleh modal dari } \\
\text { kreditur dan modal pemegang } \\
\text { saham ( Dewayanto 2011). }\end{array}$ & $\begin{array}{cc}\text { DTA }= & \\
\text { Total } & \\
\text { liabilities } & \\
& \text { Total } \\
& \text { asset } \\
( & \\
\text { Dewayanto } \\
\text { 2011) }\end{array}$ & Skala \\
\hline
\end{tabular}

\section{Teknik Analisi Data}

Penelitian ini menerapkan metode atau jenis analisis data, di antaranya:

\section{a. Statistik Deskriptif}

Penggunaan statistik deskriptif bertujuan membuat ketentuan sampel yang dipakai serta untuk mendeskripsikan variabel penelitian ini. Pengujian statistik deskriptif dilakukan berdasarkan jumlah data, standar deviasi, rata-rata, skor tertinggi dan terendah. 
Owner: Riset \& Jurnal Akuntansi

e-ISSN : 2548-9224 | p-ISSN : 2548-7507

Volume 5 Nomor 2, Agustus 2021

DOI : https://doi.org/10.33395/owner.v5i2.573

\section{b. Uji Asumsi Klasik}

Analisis regresi logistik dilakukan unttuk pengujian data pada penelitian ini, sebagai variabel nominal pada penelitian ini. Sebagai penguji pengaruh Solvabilitas, Ukuran Likuiditas, Perusahaan, dan Profitabilitas pada opini audit going concern diterapkan analisis regresi logistik. Menurut Ghozali (2018:103), regresi logistik dipakai guna melihat apakah variabel independen bisa memprediksi profitabilitas variabel dependen.

a. Uji Multikolinearitas

Dilakukan agar mengetahui terdapat tidaknya keterkaitan antar variabel pada suatu regresi. Uji inidikerjakan dengan skor Variance Inflation Factor (VIF) dan Tolerance.

Pada penelitian ini, model regresi logistik yaitu:

$$
L \underline{n}={ }^{\mathrm{Gc}}
$$

$=a+b 1 S I Z E+b 2 L I K D+b 3$ PROF $+b 4 S O L V+e$

Dimana :

$$
\underset{1-\mathrm{Gc}}{\operatorname{Ln}}=\underset{1-\mathrm{Gc}}{\mathrm{Gc}}
$$

: Opini non-going concern auditee adalah 1 atau Opini auditor fiktif adalah 1 bila laporan audit going concern.

$\begin{array}{ll}\text { SIZE } & : \text { Ukuran perusahaan } \\ \text { a } & : \text { Konstanta } \\ \text { SOLV } & : \text { Solvabilitas } \\ \text { LIKD } & : \text { Likuiditas } \\ \text { PROF } & : \text { Profitabilitas } \\ \mathrm{e} & : \text { Error term }\end{array}$

\section{Uji Hipotesis}

Penggunaan model regresi logistik pada penelitian ini berguna sebagai pengujian agar melihat pengaruh dari tiap variabel bebas pada variabel terikat. Regresi logistik menilai dampak antara 2 maupunlebih variabel. Ada beberapa tahapan untuk analisis ini, di antaranya:

\section{a. Mengukur kelayakan Model Regresi}

Penggunaan Goodnes of Fit Test Hosmer and Lemeshow tujuannya mengevaluasi kelayakan model regresi. Goodnes of Fit Test Lemeshow merupakan uji kelayakan model atau apakah model yang kita pergunakan telah sesuai. H0 tidak dapat ditolak, apabila statistik Lemeshow and Hosmer lebih besar dari0,05 (Ghozali 2018 : 346).

\section{b. Overall Model Fit (Menilai Model Fit)}

Analisis pertama terdiri dari mengukur kecocokan keseluruhan model dengan data. Hipotesis berikut dipergunakan dalam mengevaluasi kecocokan model, H0: model hipotesis cocok dengan data, Ha:model hipotesis tidak cocok dengan data. Berdasarkan hipotesis tersebut, supaya model cocok dengan data, Ha ditolak dan menerima H0. Penggunaan statistik didasarkan pada fungsi Likelihood. Model Likelihood (L) merupakan probabilitas bahwa model hipotesis mewakili input. Sebagai penguji H0 dan Ha, L ditransformasikan -2LogL. Terjadi penurunan skor antara skor awal -2LogL dengan skor -2LogL. Tahap kemudian membuktikan bahwa model hipotesis cocok dengan data. Kemungkinan hasil -2LogL memperlihatkan model regresi yang baik (Ghozali 2018: 340). 
Owner: Riset \& Jurnal Akuntansi

e-ISSN : 2548-9224 | p-ISSN : 2548-7507

Volume 5 Nomor 2, Agustus 2021

DOI : https://doi.org/10.33395/owner.v5i2.573

c. Koefisien Determinasi (R Square)

Adalah uji yang menilai kemampuan variabel bebas ketika menerangkan variabel terikat (Ghoali 2018: 212). Rentang skor R2 adalah 0 hingga 1. Apabila R2 sangat kecil, hal ini menunjukkan kemampuan variabel bebas untuk menguraikan keterbatasan variabel terikat. Selain itu, bila R2 mendekati1, artinya variabel bebas bisa menyampaikan hampir setiap informasi yang dibutuhkan gunamengestimasi variabel terikat.

d. Uji F/Uji linearitas (Pengujian Hipotesis Secara Bersamaan)

Ghozali 2018:96 menjelaskan bahwa uji pengaruh secara simultan dipergunakan dalam melihat apakah variabel bebas memberi pengaruh pada variabel terikat. Perbandingan skor F hitung dengan Ftabel dilakukan ketika Uji-F; bila skor F yang dihitung di atas skor F tabel, Ha adalah bahwa seluruh variabel bebas secara bersamaan mempengaruhi variabel terikat lainnya.

e. Uji-t/Uji keberartian koefisien (Pengujian Hipotesis Secara Individual)

Menurut Ghozali 2018:97, pengaplikasian uji parsial guna mencari tahu pengaruh setiap variabel bebas terhadap variabel terikat. Metode perhitungan terdiri dari membandingkan nilai statistik $\mathrm{T}$ dengan penilaian materialitas tabel; jika statistik yang dihitung $\mathrm{T}>\mathrm{T}$ tabel, hipotesis alternatif diterima dikarenakan variabel bebas mempengaruhi variabel terikat.

\section{Statistik Deskriptif}

\section{HASIL}

Pada penelitian ini, analisis statistik deskriptif terdiri atas median, mean, standar deviasi, dan modus. Sebanyak 132 sampel perusahaan diambil sebagai sampel. Pengolahan data dalam penelitian ini memakai hasil SPSS yang ditunjukkan tabel statistik deskriptif di bawah :

Tabel 3. Descriptive Statistics

\begin{tabular}{|l|c|r|r|r|r|}
\hline & $\mathrm{N}$ & Minimum & Maximum & \multicolumn{1}{c|}{ Mean } & Std. Deviation \\
\hline OPINI & 132 & .00 & 1.00 & .5909 & .49354 \\
SIZE & 132 & 5.97 & 13.35 & 10.0976 & 2.10032 \\
CR & 132 & .17 & 4636.52 & 38.3149 & 403.28685 \\
ROA & 132 & .00 & .92 & 1019 & .11368 \\
DTA & 132 & .06 & 1.91 & .3893 & .24438 \\
Valid N & & & & \\
(listwise) & 132 & & & & \\
\hline
\end{tabular}

a. OPINI

Menurut hasil analisis, didapatkan skor minimum variabel Opini audit going concern yaitu 0,maksimum 1, standar deviasi 0,49354 dan mean 0,5909.

b. SIZE

Menurut hasil analisis, variabel Ukuran Perusahaan nilai minimum 5,97, maksimum 13,35, mean10,0976 dan standar deviasi 2,10032.

c. $\mathrm{CR}$

Berdasarkan hasil analisis deskriptif variabel Likuiditas nilai minimum 0,17 , maksimum 4636,52, mean 38,3149 dan standar deviasi 403,28685.

d. ROA 
Owner: Riset \& Jurnal Akuntansi

e-ISSN : 2548-9224 | p-ISSN : 2548-7507

Volume 5 Nomor 2, Agustus 2021

DOI : https://doi.org/10.33395/owner.v5i2.573

Menurut hasil analisis deskriptif variabel Profitabilitas skor terendah 0,00, mean 0,1019, tertinggi 0,92,dan standar deviasi 0,11368 .

e. DTA

Menurut hasil analisis deskriptif variabel Solvabilitas skor mean 0,3893, terendah 0,06, tertinggi 1,91 ,serta standar deviasi 0,24438 .

\section{Uji Asumsi Klasik}

a. Uji Multikolonieritas

Penggunaan uji ini guna melihat nilai dari tolerance dan VIF. Bila skor Tolerance $>0,10$ ataupun skor VIF $<10$, jadi multikolo nieritas bebas mengajukan model. Hasil ujinya bisa diketahui pada tabel di bawah:

Tabel 4. Uji Multikolonieritas

$$
\text { Coeffiecints }^{3}
$$

\begin{tabular}{|c|c|c|}
\hline \multirow[b]{2}{*}{ Model } & Collinearity Statistics & \multirow[b]{2}{*}{ VIF } \\
\hline & Tolerance & \\
\hline SIZE & .873 & 1.146 \\
\hline $\mathrm{CR}$ & .967 & 1.034 \\
\hline ROA & .922 & 1.085 \\
\hline DTA & .954 & 1.048 \\
\hline a. Depende & Variable: OPINI & \\
\hline
\end{tabular}

Dari tabel tersebut menunjukkan nilai tolerance variabel SIZE (X1), CR (X2), ROA (X3) dan DTA (X4) besarnya masing-masing 0,873; 0,967; 0,922 dan 0,954 > 0,10. Dan skor VIF SIZE (X1), CR

(X2), ROA (X3) dan DTA (X4) masing-masing sebesar 1,146; 1,034; 1,085 dan 1,048 lebih kecil dari 10. Dari penjelasan tersebut bisa ditarik kesimpulan bahwa tidak terjadi multikolonieritas antara variabel bebas sehingga data telah terdistribusi secara normal.

\section{Pengujian Hipotesis}

\section{a. Mengukur Kelayakan Model Regresi}

Penggunaan Goodnes of Fit Test Hosmer and Lemeshow untuk mengevaluasi model regresi yang layak. H0 diterima, jika nilai signifikansi uji ini menghasilkan nilai di atas 0,05. Dengan kata lain, model bisa memperkirakan pengamatannya, serta model tersebut bisa diterima. Hasil tesnya terlihat di tabel di bawah:

Tabel 5. Hosmer and Lemeshow Test

\begin{tabular}{|l|r|r|r|}
\hline Step & Chi-square & Df & \multicolumn{1}{c|}{ Sig. } \\
\hline 1 & 10.721 & 8 & .218 \\
\hline
\end{tabular}

Sumber : diolah oleh SPSS versi 22

Menurut tabel tersebut didapatkan skor Chi-square 10,721, angka signifikansi 0,218, dan df 8. Sesuai hasil ini, dapat diketahui bahwa angka signifikansi >0,05, dan menerima H0, maka tidak ditemukan perbedaan antara klasifikasi yang diobservasi dan klasifikasi prediksi. Demikian, bisa ditarik kesimpulan bahwa model regresi logistik yang dipakai konsisten dengan kelengkapan data (fit).

\section{b. Overall Model Fit (Menilai Model Fit)}




\section{Owner: Riset \& Jurnal Akuntansi}

e-ISSN : 2548-9224 | p-ISSN : 2548-7507

Volume 5 Nomor 2, Agustus 2021

DOI : https://doi.org/10.33395/owner.v5i2.573

Uji model fit dirancang guna mengetahui kecocokan antara model dengan data setelah dansebelum memasukkan variabel bebas ke dalam model. Cara melakukan verifikasi yaitu dengan memperbandingkan skor -2log-likelihood awal $(2 \mathrm{LL})($ nomor blok $=0$ ) dan skor 2log-likelihood terakhir(2LL) (nomor blok $=1$ ). Jika hasil uji menunjukkan penurunan skor awal antara -2LL dan -2LL di akhir pengujian (jumlah blok =1), ini memperlihatkan bahwa model diasumsikan fit untuk data. Penurunan skor Log Likelihood membuktikan peningkatan dalam model regresi. Hasil uji kecocokan modelditunjukkan pada tabel di bawah :

Tabel 6. Hasil Uji Fit 1

\begin{tabular}{|l|r|r|r|}
\hline \multicolumn{2}{|l|}{} & \multicolumn{1}{c|}{-2 Log } & Coefficients \\
\cline { 4 - 4 } \multicolumn{2}{|l|}{ Iteration } & Likelihood & \multicolumn{1}{c|}{ Constant } \\
\hline \multirow{2}{*}{ Step } & 1 & 178.603 & .364 \\
& 2 & 178.603 & .368 \\
& 3 & 178.603 & .368 \\
\hline
\end{tabular}

Sumber : diolah oleh SPSS Versi 22

Tabel 7. Hasil Uji Fit 2

\begin{tabular}{|l|c|r|r|c|c|c|c|}
\hline & & -2 Log & & \multicolumn{3}{|c|}{ Coeffients } & \\
\hline Literation & & Likelihood & Constant & $\mathrm{x} 1$ & $\mathrm{x} 2$ & $\mathrm{x} 3$ & $\mathrm{x} 4$ \\
\hline step 1 & 1 & 176.837 & .780 & -.035 & -.001 & .081 & -0.142 \\
\hline & 2 & 176.655 & .803 & -.036 & -.001 & .085 & -0.149 \\
\hline & 3 & 176.589 & .804 & -.036 & -.001 & .086 & -0.15 \\
\hline & 4 & 175.556 & .805 & -.306 & -.001 & .086 & -0.151 \\
\hline & 5 & 175.526 & .807 & -.306 & -.002 & .088 & -0.154 \\
\hline & 6 & 175.338 & .821 & -.035 & -.006 & .096 & -0.175 \\
\hline & 7 & 175.031 & 1.189 & -.020 & -.114 & .305 & -0.689 \\
\hline & 8 & 175.029 & 1.217 & -.020 & -.177 & .302 & -0.711 \\
\hline & 9 & 175.029 & 1.217 & -.020 & -.117 & .302 & -0.711 \\
\hline
\end{tabular}

Sumber : diolah oleh SPSS versi 22

Tabel 4 dan 5 memperlihatkan perbandingan antara skor -2LL di blok kedua dan skor -2LL di blok pertama. Menurut hasil perhitungan skor -2LL, diketahui bahwa skor blok pertama (nomor blok =0) yaitu 178 603, serta skor blok kedua -2LL (nomor blok =1) yaitu 174029. Berdasarkan hasil tersebut ditarik kesimpulan bahwa model regresi kedua lebih baik sebab blok pertama menurun ke blok kedua.

\section{c. Koefisien Determinasi}

Tujuan dari model Summary untuk menentukan sejauh mana kombinasi variabel bebas, yakni solvabilitas, likuiditas, ukuran perusahaan, serta profitabilitas, dapat menerangkan variabel terikat, yakni Opini Audit Going Concern. Hasil Summary model ditunjukkan pada tabel di bawah:

Tabel 8. Model Summary 
Owner: Riset \& Jurnal Akuntansi

e-ISSN : 2548-9224 | p-ISSN : 2548-7507

Volume 5 Nomor 2, Agustus 2021

DOI : https://doi.org/10.33395/owner.v5i2.573

\begin{tabular}{|r|c|c|cr|}
\hline & -2 Log & \multicolumn{2}{|c|}{$\begin{array}{c}\text { Cox \& Snell R } \\
\text { Square }\end{array}$} & \multicolumn{2}{|c|}{ Nagelkerke R } \\
Step & Likelihood & .034 & & .046 \\
\hline 1 & 174.029 & & .034 \\
\hline
\end{tabular}

Sumber : diolah oleh SPSS versi 22

Dari tabel 6 didapat hasil uji model nilai Nagelkerke R Square 0,046\% atau 4,6\%, yang artinya bahwa variabel terikatnya yaitu Opini Audit Going Concern dari variabel bebas bisa menjelaskan Solvabilitas, Profitabilitas, Likuiditas 4,6\%, sementara sisanya 95,4\% diuraikan oleh faktor atau variabel di luar model penelitian.

\section{d. Uji Hipotesis Secara Bersamaan (Uji F/Uji linearitas)}

Uji ini dipergunakan untuk memeriksa apakah variabel profitabilitas, likuiditas, ukuran perusahaan, dan solvabilitas secara bersamaan mempengaruhi Opini Audit Going Concern. Hasil Omnibus Test of Model Coefficient bisa diamati pada tabel di bawah:

\begin{tabular}{|ll|r|r|r|}
\multicolumn{2}{|c|}{ Tabel 9. Omnibus Test of Model Coefficient } \\
\hline \multirow{2}{*}{ Step 1 } & Step & 4.574 & 4 & .000 \\
& & & & \\
& Blok & 4.574 & 4 & .000 \\
& Model & 4.574 & 4 & .000 \\
\hline
\end{tabular}

Sumber: diolah oleh SPSS versi 22

Berdasarkan tabel di atas secara bersamaan menunjukkan profitabilitas, ukuran perusahaan, solvabilitas dan likuiditas, serta bisa juga menginterpretasikan opini audit going concern. Hasilnya membuktikan bahwa Chi-square adalah 4.574 dengan df 4 atau signifikan $0,000<0,05$. Sehingga menandakan bahwa menerima hipotesis, jadi bisa diambil kesimpulan bahwa secara bersamaan likuiditas, profitabilitas, ukuran perusahaan, serta solvabilitas memberi pengaruh opini audit going concern.

\section{f. Uji Hipotesis Secara Individual (Uji-t/Uji keberartian koefisien)}

Teknik analisis data regresi logistik pada penelitian dipergunakan dalam melihat pengaruh parsialsetiap variabel bebas pada variabel terikat. Hasil analisis ditunjukkan tabel berikut:

Tabel 10. Variables In The Equation

\begin{tabular}{|rc|r|r|r|r|r|r|}
\hline & & \multicolumn{1}{|c|}{ B } & \multicolumn{1}{|c|}{ S.E } & Wald & Df & Sig & $\operatorname{Exp}(\mathrm{B})$ \\
\hline Step 1 & X1 & -.020 & .092 & .048 & 1 & .826 & .980 \\
& X2 & -.117 & .076 & 2.389 & 1 & .122 & .890 \\
& X3 & .302 & 1.687 & .032 & 1 & .858 & 1.353 \\
& X4 & -.711 & .843 & .710 & 1 & .399 & .491 \\
\multicolumn{1}{|c|}{ Constant } & 1.217 & 1.133 & 1.153 & 1 & .283 & 3.376 \\
\hline
\end{tabular}

Sumber: diolah oleh SPSS versi 22

Model regresi logistik penelitian ini di antaranya:

$L n=\frac{\mathrm{Gc}}{1-\mathrm{Gc}}=1,217-0,020 \mathrm{X} 1-0,117 \mathrm{X} 2+0,302 \mathrm{X} 3-0,711 \mathrm{X} 4$ 
Owner: Riset \& Jurnal Akuntansi

e-ISSN : 2548-9224 | p-ISSN : 2548-7507

Volume 5 Nomor 2, Agustus 2021

DOI : https://doi.org/10.33395/owner.v5i2.573

a. Variabel konstan model regresi logistik berkoefisien positif 1,217, artinya bila variabel lainnya diambil 0, maka opini audit going concern akan meningkat 1,217.

b. Variabel Likuiditas (X2) membuktikan koefisien negatif -0,117 dan nilai signifikan 0,122> 0,05, makamenolak $\mathrm{H} 2$ ataupun Likuiditas (X2) tidak mempengaruhi secara bermakna pada opini audit goingconcern (Y).

c. Variabel Ukuran Perusahaan (X1) membuktikan koefisien negatif -0,020 dengan angka sig. 0,826>0,05, maka menolak H1 ataupun Ukuran Perusahaan (X1) tidak mempengaruhi secara bermakna pada opini audit going concern (Y).

d. Variabel Solvabilitas (X4) membuktikan koefisien negative -0,711 dan angka sig. 0,399 > 0,05, maka menolak H4 atau Solvabilitas (X4) tidak mempengaruhi secara signifikan pada (Y).

e. Variabel Profitabilitas (X3) membuktikan koefisien positif 0,302 dan angka sig. 0,858 > 0,05, maka menolak H3 ataupun Profitabilitas (X3) tidak mempunyai pengaruh signifikan pada (Y).

\section{PEMBAHASAN}

Pengaruh Ukuran Perusahaan Terhadap Opini Audit Going Concern pada Perusahaan Manufaktur yang Terdaftar di BEI Tahun 2018-2020

Hipotesis pertama dari penelitian ini menetapkan bahwa Ukuran tidak memberi pengaruh bermakna pada Opini Audit Going Concern di perusahaan manufaktur yang tercatat di BEI sepanjang 2018-2020. Hasil (Uji-T) menunjukkan bahwa Ukuran Perusahaan tidak mempengaruhi Opini Audit Going Concern. Hal tersebut sesuai dengan penelitian Friska (2015) yang memperlihatkan bahwa Ukuran Perusahaan tidak mempengaruhi secara bermakna pada Opini Audit Going Concern.

\section{Pengaruh Likuiditas Terhadap Opini Audit Going Concern pada Perusahaan Manufaktur yang Terdaftar di BEI Tahun 2018-2020}

Hipotesis kedua dalam penelitian ini menyatakan Likuiditas secara tidak signifikan dan tidak memberi pengaruh pada Opini Audit Going Concern pada perusahaan manufaktur yang tercatat di BEI periode 2018-2020. Dimana hasil (uji T) menunjukkan Likuiditas tidak mempengaruhi Opini Audit Going Concern. Hal demikian sejalan dengan penelitian Feri Setiawan (2015) menunjukkan hasil Opini Audit Going Concern tidak dipengaruhi Likuiditas.

\section{Pengaruh Profitabilitas Terhadap Opini Audit Going Concern pada Perusahaan Manufaktur yang Tercatat di BEI Periode 2018-2020}

Hipotesis ketiga pada penelitian ini menyatakan Profitabilitas tidak memberi pengaruh dan tidak bermakna pada Opini Audit Going Concern di perusahaan manufaktur yang tercatat di BEI tahun 2018- 2020.

Pengaruh Solvabilitas Terhadap Opini Audit Going Concern pada Perusahaan Manufakturyang Terdaftar di BEI Periode 2018-2020

Hipotesis keempat dalam penelitian ini menyebutkan Solvabilitas tidak memberi pengaruh dan tidak bermakna pada Opini Audit Going Concern. Dimana hasil(uji T) membuktikan Solvabilitas tidak mempengaruhi Opini Audit Going Concern. Hal demikian sejalan dengan penelitian Feri Setiawan (2015)hasilnya membuktikan Opini Audit Going Concern tidak dipengaruhi Solvabilitas.

\section{KESIMPULAN}

Setelah melakukan uji data maka kesimpulan yang diambil pada penelitian yaitu: Variabel Profitabilitas menyatakan bahwa tidak mempengaruhi secara bermakna pada opini audit going 
Owner: Riset \& Jurnal Akuntansi

e-ISSN : 2548-9224 | p-ISSN : 2548-7507

Volume 5 Nomor 2, Agustus 2021

DOI : https://doi.org/10.33395/owner.v5i2.573

concern secara parsial di Perusahaan Manufaktur yang Tercatat di BEI Tahun 2018-2020, Variabel Ukuran Perusahaan menyatakan bahwa tidak mempengaruhi secara bermakna pada opini audit going concern secara parsial di Perusahaan Manufaktur yang Tercatat di BEI Tahun 2018-2020, Variabel Likuiditas menyatakan bahwa tidak memberi pengaruh signifikan pada opini audit going concern secara parsial di Perusahaan Manufaktur yang Tercatat di BEI Periode 2018- 2020, Variabel Solvabilitas menyatakan bahwa tidak mempengaruhi secara bermakna pada opini audit going concern secara individual di Perusahaan Manufaktur yang Tercatat di BEI Periode 2018-2020.

\section{REFERENSI}

A journal of Practive \& Theory, 32(1), 352-384.

Carson, E. et.al. (2020). Audit Reporting For Going concern Uncertaunty: A Research Synthesis. Auditing.

Ghozali, I. (2018). Aplikasi Analisis Multivariate dengan Program IBM SPSS 19. Semarang: Badan Penerbit Universitas Diponegoro.

Institut Akuntan Publik Indonesia (IAPI). (2019). Pertimbangan Auditor atas Kemampuan Entitas dalam Mempertahankan Kelangsungan Hidupnya. Jakarta : PSA No. 30. Standar Profesional Akuntan Publik (SPAD).

Institut Akuntan Publik Indonesia. (2019). Standar Profesional Akuntan Publik. Jakarta: Selemba Empat.

Lie, Christian, dkk. (2017). Pengaruh Likuiditas, Solvabilitas, Profitabilitas terhadap Opini Audit Going Concern (Studi Empiris Pada Perusahaan Manufaktur di BEI). Berkala Akuntansi dan Keuangan Indonesia, Vol. 1, No. 2, Hlm 84 - 105.

Nazir. (2019). Analisis pengaruh Opini Audit Tahun Sebelumnya, Likuiditas, Solvabilitas dan Profitabilitas terhadap Opini Audit Going concern pada perusahaaan Manufaktur yang Terdaftar di Bursa Efek Indonesia. UG Jurnal, Vol. 6, No.12, Hm: 14-19

Mulyadi. (2020). Auditing Buku 1 Edisi Keenam. Jakarta: Selemba Empat.

Sutedja, C. (2017). Faktor-faktor yang Berpengaruh terhadap Pemberian Opini Audit Going Concern Pada perusahaan Manufaktur. Jurnal Akuntansi Kontemporer. Vol. 2, No. 2, Juli: 15 